\title{
Fluoressensie-spektroskopie van mikro-grootte deeltjies in 'n optiese lokval
}

\author{
Outeurs: \\ Ané Kritzinger \\ V Rodríguez-Fajardo \\ SA Nsibande \\ A Forbes \\ PBC Forbes \\ Affiliasie: \\ Departement Chemie, \\ Universiteit van Pretoria \\ Privaatsak X20, Hatfield \\ 0028, Suid-Afrika \\ Korresponderende outeur: \\ Ané Kritzinger \\ E-pos: \\ anek1205@gmail.com \\ Hoe om hierdie artikel aan \\ te haal: \\ Ané Kritzinger, V Rodríguez- \\ Fajardo, SA Nsibande, \\ A Forbes, PBC Forbes, \\ Fluoressensie-spektroskopie \\ van mikro-grootte deeltjies \\ in 'n optiese lokval, \\ Suid-Afrikaanse Tydskrif \\ vir Natuurwetenskap en \\ Tegnologie 39(1) (2020). \\ https://doi.org/10.36303/ \\ SATNT.2020.39.1.818 \\ Kopiereg: \\ C 2020. Authors. \\ Licensee: Die Suid- \\ Afrikaanse Akademie vir \\ Wetenskap en Kuns. \\ Hierdie werk is onder \\ die Creative Commons \\ Attribution License \\ gelisensieer.
}

Fluorescence spectroscopy of micro-sized particles in an optical trap: Optical traps use tightly focused light to trap and manipulate particles. This research focuses on setting up an optical tweezer and trapping quantum dot nanoparticles (QDs) with the aid of micro-sized beads. By measuring the fluorescence of the trapped beads, the understanding of QD-based sensors can be improved.

Optiese lokvalle (ook bekend as optiese pinsette) gebruik nou-gefokusde lig om deeltjies vas te vang en te manipuleer. Arthur Ashkin wat baanbrekerswerk vir dié tegnologie gedoen het, het in 2018 die Nobelprys vir Fisika daarvoor ontvang. Sedert die ontdekking van optiese lokvalle, het hierdie nie-indringende tegniek verskeie toepassings in verskillende dissiplines gevind, insluitend fisika, biologie en chemie.

Optiese lokvalle in samewerking met analitiese tegnieke kan gebruik word om stowwe te identifiseer met konsentrasies so laag as selfs 'n zeptomol $\left(10^{-21}\right)$. Ons navorsing ondersoek verdere toepassings van die optiese lokval as 'n analitiese instrument spesifiek in samewerking met fluoressensie-spektroskopie.

Die navorsingsprojek fokus op die opstel van 'n optiese lokval wat mikro-grootte deeltjies, gebind aan kwantumkol nanodeeltjies, vasvang en die fluoressensie daarvan meet. Die optiese eienskappe van kwantumkolle maak hulle ideaal om verskeie stowwe in 'n monster te identifiseer, insluitend plaagdoders, proteïene en ione. Deur dus optiese lokvalle te gebruik, sal die begrip en doeltreffendheid van kwantumkol-gebaseerde sensors verbeter word.

Die eksperimentele opstelling van die optiese lokval sluit 'n ruimtelike ligmanipuleerder (RLM) in wat die vorm, digitale fokus en voortplanting van die lig beheer. Die RLM maak dit moontlik om verskillende vorms gestruktureerde lig as 'n lokval te gebruik en veelvoudige lokvalle te genereer. Ander komponente sluit 'n objektieflens in wat die ligstraal fokus en 'n ladinggekoppelde toestel wat die vasgevangde deeltjies afneem en die fluoressensie daarvan meet.

Die kwantumkolle word gebind aan mikro-grootte deeltjies, aangesien hulle te klein (ongeveer $5 \mathrm{~nm}$ ) is om deur die instrument vasgevang te word. CdSe/ZnS kwantumkolle wat omring is met L-sisteïen word gesintetiseer en ondersoek. Die doel van die L-sisteïn is om die kwantumkolle meer oplosbaar in water te maak en die bindingsreaksie aan die mikro-grootte deeltjies moontlik te maak. Diékwantumkolleword gebind aan kommersiële polistireendeeltjies met 'n deursnee van twee mikrometer. As die kwantumkolle aan die mikro-grootte deeltjies gekoppel is, kan dié deeltjies vasgevang word deur die optiese lokval en hul fluoressensie kan gemeet word.

Toekomstige werk sluit in om die kwantumkol-gebaseerde sensors saam met die lokval te gebruik as 'n sensitiewe analitiese instrument om byvoorbeeld skadelike onkruiddoders soos atrasien in watermonsters op te spoor.

Hierdie navorsing fokus dus op die verdere oorbrugging van fisika en chemie en om die potensiaal van optiese lokvalle in analitiese chemie te beklemtoon en word gedoen in samewerking met die Departement Fisika van die Universiteit van die Witwatersrand.

Nota: ' $n$ Seleksie van referaatopsommings: Studentesimposium in die Natuurwetenskappe, 31 Oktober - 1 November 2019 Universiteit van die Vrystaat. Reëlingskomitee: Prof Rudi Pretorius (Departement Geografie, Universiteit van Suid-Afrika); Dr Hertzog Bisset (Suid-Afrikaanse Kernenergie-korporasie; Dr Ernie Langner (Departement Chemie, Universiteit van die Vrystaat) en Dr Wynand Nel (Departement Rekenaarwetenskap en Informatika, Universiteit van die Vrystaat). 